\title{
Movement patterns, home range, and habitat utilization of adult kelp bass Paralabrax clathratus in a temperate no-take marine reserve
}

\author{
Christopher G. Lowe*, Darin T. Topping, Daniel P. Cartamil, Yannis P. Papastamatiou
}

Dept. of Biological Sciences, California State University Long Beach, 1250 Bellflower Blvd., Long Beach, California 90840, USA

\begin{abstract}
Home range, activity patterns, site fidelity and habitat preference of the kelp bass Paralabrax clathratus were determined from 12 adult fish tracked using acoustic telemetry within a temperate no-take marine reserve $\left(0.13 \mathrm{~km}^{2}\right)$. Home range sizes ranged from 33 to $11224 \mathrm{~m}^{2}$, averaging $3349 \pm 3328 \mathrm{~m}^{2}( \pm \mathrm{SD})$, but did not correlate with fish size. Fish were active and occupied similar-sized activity spaces during both day and night. Kelp bass exhibited a high degree of site fidelity, remaining resident in core areas for up to $3 \mathrm{yr}$. Relative to the total amount of available habitat, kelp bass showed a habitat selection preference for rock boulder, rock rubble and kelp habitat. These habitats offer high vertical relief, shade and large holes for shelter, and may attract and facilitate prey capture. Average home range size was $3 \%$ of the area of the reserve. Only 1 of 12 tracked fish crossed the reserve boundary, but this accounted for less than $5 \%$ of the fish's time. Natural habitat breaks along the reserve boundary may have further limited adult kelp bass movements. The small home ranges and high site fidelity of kelp bass in this reserve indicate that the reserve is effective in protecting the resident adult stock.
\end{abstract}

KEY WORDS: Movements · Diel · Site fidelity · Marine reserves · Activity · Habitat preference

\section{INTRODUCTION}

No-take marine reserves are being considered as a new tool in fisheries management; however, despite the growing empirical evidence that no-take reserves increase fish abundance, density, size, and recruitment, debate over reserve placement and size continues (Dahlgren \& Sobel 2000, Roberts 2000, Walters 2000, Roberts et al. 2001). Because one of the primary applications of no-take marine reserves is to protect adult reproductive stock, which may serve to supply larvae and juveniles to adjacent unprotected areas, reserves for non-migratory species must be large enough at minimum to encompass the average daily movements of adult fishes. If the majority of individuals within the population have home ranges larger than the area of the reserve itself, then the fish will be exposed to fishing pressure a high percentage of the time, and as a result, the effectiveness of the reserve will be reduced
(Kramer \& Chapman 1999). However, due to the challenges of quantifying movements of marine fishes, very few studies have been done to determine the home range sizes, activity patterns and habitat preferences of many species (e.g. Matthews 1990a, Holland et al. 1993, 1996, Meyer et al. 2000, Starr et al. 2002). In addition, many of these studies have focused on tropical and subtropical reef fishes or have used inadequate methods for quantifying home ranges and habitat utilization.

Quantifying movement patterns of fishes over various spatial and temporal scales poses distinct challenges, and many methods have limited applications. Historically, determination of movement patterns and habitat preferences of fishes has been through fisherydependent mark and recapture or visual (in situ) observations. Although mark and recapture can be a useful tool for determining dispersal, growth, and mortality, it is not an adequate tool for determining home range or daily space use of fish (Zeller 1999). Visual observations 
can be useful in determining species density, habitat utilization and behavior (i.e. feeding, agonistic responses, mating), but they are generally limited to relatively short, daytime observations. In addition, diver presence may influence the fish's behavior, thus limiting the value of these observations for quantifying movement patterns (Kulbicki 1998). One of the most effective ways to determine home range size, diel activity patterns, site fidelity, and habitat preferences of fish species is through the use of acoustic telemetry (Holland et al. 1996, Zeller 1999, Meyer et al. 2000). A number of studies have been conducted using acoustic telemetry to determine home range size and activity patterns of coral reef fishes within tropical and subtropical reserves (e.g. Holland et al. 1993, 1996, Zeller \& Russ 1998, Meyer et al. 2000); however, there have been very few studies on the home ranges of temperate fishes, and fewer still within reserves (e.g. Matthews 1990b, Lowry \& Suthers 1998, Mitamura et al. 2002, Starr et al. 2002).

Kelp bass Paralabrax clathratus is a popular food and gamefish found around nearshore rocky reefs and kelp habitats from Baja California to Monterey Bay, California (Quast 1968, Miller \& Lea 1972). Increased recreational and commercial fishing pressure over the last 50 yr has resulted in a decrease in landings of kelp bass in California (Rodgers-Bennett 1991, Allen \& Hovey 2001). In situ observations of this generalist carnivore have indicated that they are diurnally active and show strong site fidelity (Limbaugh 1955, Hobson et al. 1981). Mark and recapture studies suggest larger-scale movements and dispersal of young kelp bass and less movement from older fish (Limbaugh 1955, Young 1963, Hartney 1996). These characteristics suggest that kelp bass may benefit from suitably placed no-take marine reserves, to aid in the recovery of adult reproductive stocks. In order to determine the proper placement and size of a marine reserve to protect adult kelp bass, detailed knowledge of their movement patterns and habitat utilization are required.

We used acoustic telemetry techniques to determine home range size and site fidelity, activity patterns, and habitat preference of adult kelp bass within the Catalina Marine Science Center Marine Life Refuge (CMLR) at Santa Catalina Island, California. Home range sizes and habitat preferences of fish tracked were used to assess whether the reserve was of adequate size and habitat composition to protect the adult reproductive stock.

\section{MATERIALS AND METHODS}

Study site. This study was conducted at Catalina Marine Science Center Marine Life Refuge (CMLR),

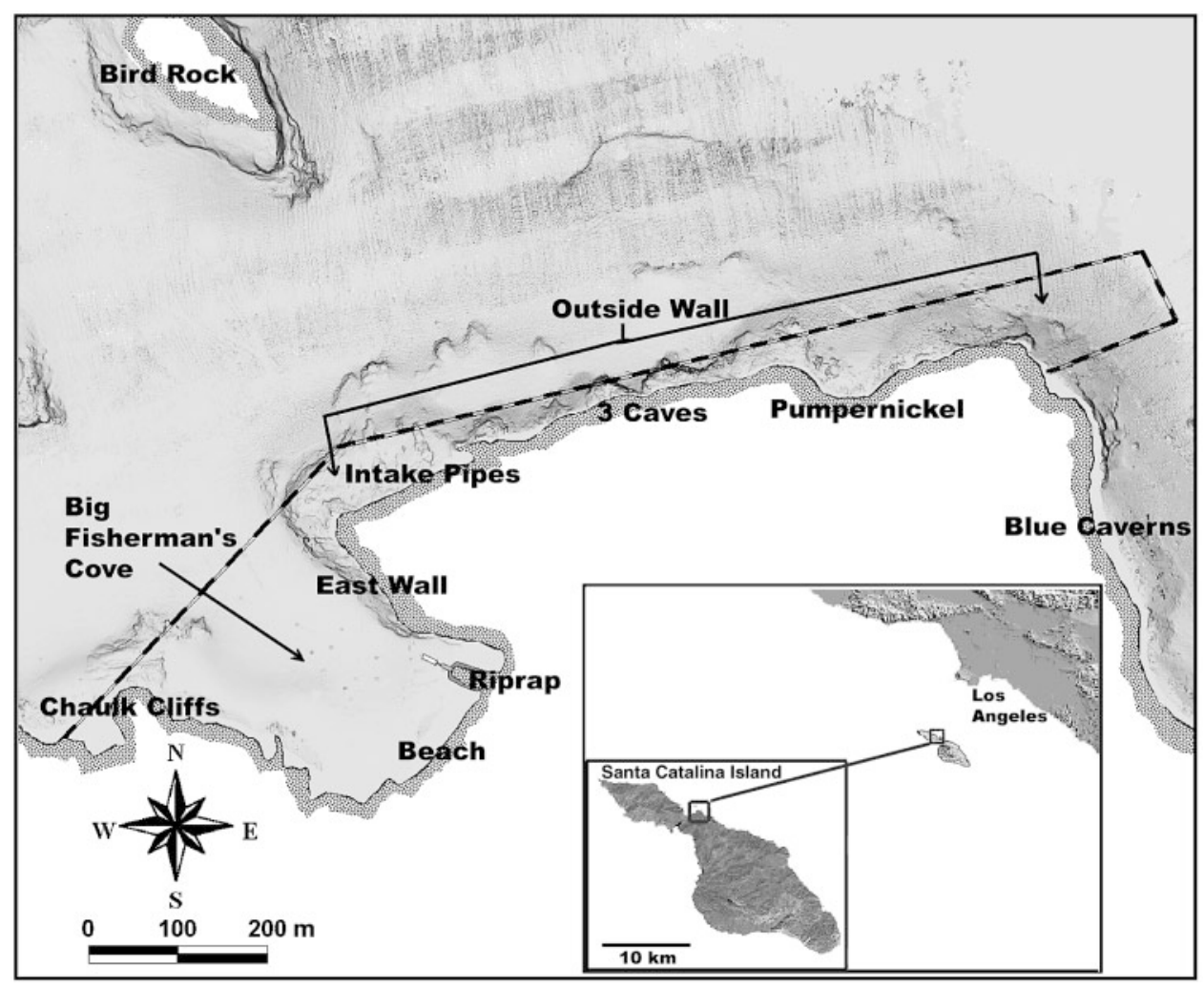

Fig. 1. Shaded relief map of Catalina Marine Science Center Marine Life Reserve (CMLR) at Santa Catalina Island, California, detailing bottom topography. Reserve boundary is represented by black dashed line. Arrows indicate distinct areas of the CMLR: Big Fisherman's Cove or outside wall reef area. Inset map shows the location of Santa Catalina Island off the coast of southern California 
Santa Catalina Island, California $\left(33^{\circ} 26^{\prime} \mathrm{N}, 118^{\circ} 29^{\prime} \mathrm{W}\right)$. CMLR was designated a marine reserve in 1988, and prior to January 2003 was one of the larger no-take reserves in southern California (reserve area = $130000 \mathrm{~m}^{2}$ ) (Fig. 1). Habitat types in CMLR are typical of the offshore islands in California and include kelp beds, rocky reef, and sandy substratum, but also possess artificial habitats (e.g. floating dock, pier, stone rip rap, moorings).

Acoustic tracking. Kelp bass were caught using barbless hooks and line at various locations within CMLR. Fish were brought aboard the fishing vessel and anesthetized with MS-222 (Finquel ${ }^{\mathrm{TM}}$ Conc. $0.15 \mathrm{~g}$ $\mathrm{l}^{-1}$ ). Once anesthetized, a $1.5 \mathrm{~cm}$ incision was made approximately $1 \mathrm{~cm}$ from the ventral midline between the base of the pelvic fins and the vent, and a small acoustic transmitter (Model V8-1L, $8 \mathrm{~mm}$ diam. × $24 \mathrm{~mm}$; Vemco) was implanted in the peritoneal cavity. The incision was closed with 2 to 3 surgical sutures (Ethicon Chromic Gut 2-0), and the fish were transferred to aerated seawater for recovery. Each fish was measured, weighed and tagged externally in the dorsal musculature with a spaghetti dart tag for visual identification. The sex of fish could not be determined due to the lack of sexual dimorphism in this species. Acoustic transmitters had carrier frequencies of 65 to $78 \mathrm{kHz}$ and a nominal battery life of $28 \mathrm{~d}$. Transmitters were coated in a mixture of beeswax and paraffin (2.3:1) and covered with antibiotic ointment to minimize immuno-rejection resulting from internal implantation. Preliminary laboratory tag retention tests indicated $100 \%$ survivorship and tag retention during a 6 mo pilot study.

Tracking commenced immediately following release of the fish at the site of capture. Tracks were conducted from a $5 \mathrm{~m}$ Boston Whaler equipped with a hullmounted directional hydrophone (Vemco model V10) and a receiver (Vemco model VR-60) as described in Holland et al. (1993). Each fish's geographical position was determined at 15 min intervals using GPS. Kelp bass were tracked over multiple, continuous $24 \mathrm{~h}$ periods for up to 1 mo. Tracking positional accuracy was determined to be less than $5 \mathrm{~m}$ depending on the individual tracking and water depth.

Acoustic monitoring. To quantify longer-term site fidelity, 4 additional kelp bass caught at various locations within CMLR were surgically fitted with individually coded transmitters (Vemco V8-2L-R256, $8 \mathrm{~mm}$ diam. $\times 30 \mathrm{~mm}$ ), specifically designed for detection by automated acoustic monitors. Transmitters were surgically implanted using the same procedures described for acoustic tracking.

Automated acoustic monitors (Vemco model VR1) were strategically placed throughout the reserve for continuous monitoring of kelp bass tagged with coded transmitters. Monitors were secured in mid-water
( 10 $\mathrm{m}$ from surface), although each monitor's depth from the substratum varied depending on location. Tests were conducted prior to tagging, and the acoustic detection range of monitors was determined to be approximately $150 \mathrm{~m}$. Data from monitors were downloaded every 3 to 4 mo.

Data analysis. Kelp bass positional fixes were plotted on a geo-referenced map of CMLR and analyzed in a GIS program (ArcView 3.2) using the Animal Movements Analyst Extension (AMAE) (Hooge \& Eichenlaub 2000). We determined the home range of each kelp bass using GIS-AMAE to calculate a 95\% kernel utilization distribution (KUD) (Worton 1987), the area that a fish has a $95 \%$ probability of being found within, during a given time. A bootstrap analysis was done to determine the minimum number of positional fixes required to calculate a robust home range estimate, by plotting the calculated home range size as a function of number of positional fixes (Zeller 1997, Seaman et al. 1999). For each fish, KUDs were also calculated for daytime and nighttime periods in order to ascertain diel patterns in spatial utilization, and day and night KUDs were compared for each fish using a paired $t$-test. The relationship between fish standard length and home range size was determined using a linear regression.

Site fidelity of kelp bass was determined using acoustic tracking and monitoring data. We used AMAE's linearity index, which is a ratio of the distance between the initial and final positional fix of the fish and the total cumulative distance the fish traversed during the entire track, as a measure of site fidelity (Zeller 1997). Site fidelity was also quantified by calculating the amount of area overlap among subsequent $24 \mathrm{~h}$ activity spaces. Longer-term site fidelity (up to $4 \mathrm{mo}$ ) was quantified using data from each acoustic monitor to determine the total number of days fish with coded transmitters were detected in the vicinity of each monitor.

The geological components of fish habitat were interpreted from a multibeam, side-scan sonar map of CMLR and adjacent areas (H. G. Greene \& R. Kvitek unpubl. data; $2 \mathrm{~m}$ grid resolution) and plotted in GIS. The location of giant kelp Macrocystis pyrifera, the biological component of habitat in the reserve, was determined by recording GPS positions of kelp canopy and individual fronds, in order to create a geo-referenced kelp coverage map for the GIS. Kelp distribution was only quantified in spring 2001; however, only minor seasonal changes were observed in kelp distribution over the study period. Habitat utilization in CMLR was determined by layering fish positions over the geo-referenced habitat maps and calculating the proportions of time each fish spent associated with each habitat. A habitat selection index (HSI) was used to determine each fish's preference or avoidance of those habitats available within the study area. 
This index is calculated by dividing the percentage of total fixes within a KUD occurring in each habitat (\% used) by the percentage of each habitat type available, thus the degree of preference or avoidance is shown by the degree of deviation in a positive or negative direction from a value of 1 (Winter \& Ross 1982). The percentage of habitat available for each fish was determined by quantifying the proportion of each habitat type within a minimum convex polygon encompassing all positional fixes for each fish. The relationship between home range size and percentage of each habitat type utilized within each home range was determined using a multiple regression (SAS 8.02).

\section{RESULTS}

Twelve adult kelp bass (25 to $40 \mathrm{~cm}$ standard length [SL]) were each tracked for up to $120 \mathrm{~h}$ for up to 5 continuous $24 \mathrm{~h}$ periods over the course of 1 mo between March 1999 and September 2001 (Table 1). All 12 fish surgically fitted with transmitters survived the implantation procedures. Many of these fish were directly observed by divers subsequent to their release, and all appeared in good health and behaved similarly to other untagged fish in the vicinity. Overall, we compiled 793 tracking hours for all kelp bass combined. Bootstrap analysis indicated that there was a sufficient number of positional fixes acquired for each fish to determine a robust home range. There was no significant difference between the initial and final $24 \mathrm{~h}$ activity space size (paired $t$-test: $p=0.99$ ) for fish tracked over multiple days, regardless of the time between subsequent tracks.

\section{Home range size}

Home range size (95\% KUD) of kelp bass varied greatly, ranging from 33 to $11224 \mathrm{~m}^{2}$, averaging 3349 $\pm 3328 \mathrm{~m}^{2}$ ( \pm SD) (Table 1, Fig. 2a,b). The overall maximum linear distance each fish moved also varied greatly, ranging from 15 to $220 \mathrm{~m}$, with a mean of $110 \pm 68 \mathrm{~m}$. There was no significant relationship between home range size and fish length $\left(\mathrm{r}^{2}=0.05, \mathrm{p}=\right.$ 0.50 ); however, the smaller-size classes (25 to $35 \mathrm{~cm}$ SL) had greater variability in home range size (73 to $11224 \mathrm{~m}^{2}$ ) than the largest adults (35 to $40 \mathrm{~cm} \mathrm{SL}$ ), which had home ranges varying from 33 to $3438 \mathrm{~m}^{2}$.

Only 1 (kelp bass \#10) of the 12 fish tracked crossed the reserve boundary, with $5 \%$ of the total position fixes acquired for this fish located outside of the boundary. Kelp bass \#10 had a relatively small home range $\left(1260 \mathrm{~m}^{2}\right)$, but was tracked in an area where the reserve boundary is located $50 \mathrm{~m}$ from shore. Home range areas of the $12 \mathrm{kelp}$ bass averaged $2.9 \pm 3.0 \%$ of the total reserve area $\left(130000 \mathrm{~m}^{2}\right)$, with a range of 0.03 to $8.6 \%$ (Table 1 ).

\section{Activity patterns}

All fish were active during both day and night, and there was no significant difference in amount of space used by each fish between day and night (Day: $4288 \pm$ $6662 \mathrm{~m}^{2}$, Night: $2573 \pm 3107 \mathrm{~m}^{2}$; paired $t$-test: $t=0.81$, $\mathrm{p}=0.22$ ). Although there was no difference in day/night area size, several fish showed shifts in habitat or location between day and night (Fig. 3a); however, some fish occupied the same locations between

Table 1. Paralabrax clathratus. Summary data of 12 kelp bass tracked using acoustic telemetry at Catalina Marine Science Center Marine Life Refuge (CMLR), Santa Catalina Island, California. SL = standard length. AS 1-5 represent activity space $\left(\mathrm{m}^{2}\right)$ for successive $24 \mathrm{~h}$ tracking periods. Kelp bass \#2 and 6 were not tracked in the initial $24 \mathrm{~h}$ after release. Activity spaces and home ranges were determined using the $95 \%$ kernel utilization distribution (KUD). Percent reserve size describes home range as a percentage of the total reserve area $\left(130000 \mathrm{~m}^{2}\right)$

\begin{tabular}{|c|c|c|c|c|c|c|c|c|c|c|c|c|}
\hline $\begin{array}{l}\text { Kelp } \\
\text { bass \# }\end{array}$ & $\begin{array}{l}\text { Weight } \\
\text { (g) }\end{array}$ & $\begin{array}{l}\mathrm{SL} \\
(\mathrm{cm})\end{array}$ & $\begin{array}{l}\text { Dates tracked } \\
\text { (mm/dd/yyyy) }\end{array}$ & $\begin{array}{l}\text { Hours } \\
\text { tracked }\end{array}$ & $\begin{array}{l}\text { AS } 1 \\
\left(\mathrm{~m}^{2}\right)\end{array}$ & $\begin{array}{l}\text { AS 2 } \\
\left(\mathrm{m}^{2}\right)\end{array}$ & $\begin{array}{l}\text { AS 3 } \\
\left(\mathrm{m}^{2}\right)\end{array}$ & $\begin{array}{l}\text { AS } 4 \\
\left(\mathrm{~m}^{2}\right)\end{array}$ & $\begin{array}{l}\text { AS } 5 \\
\left(\mathrm{~m}^{2}\right)\end{array}$ & $\begin{array}{c}95 \% \text { KUD } \\
\left(\mathrm{m}^{2}\right)\end{array}$ & $\begin{array}{c}\text { \% re- } \\
\text { serve } \\
\text { size }\end{array}$ & $\begin{array}{l}\text { Linearity } \\
\text { index }\end{array}$ \\
\hline 1 & 1452 & 37.0 & 03/06-04/03/1999 & 82 & 30 & 20 & 29 & & & 33 & 0.03 & 0.007 \\
\hline 2 & 380 & 25.2 & 04/17-05/01/1999 & 34 & & 4213 & & & & 2266 & 1.74 & 0.012 \\
\hline 3 & 486 & 27.8 & 09/24-10/09/1999 & 52 & 6852 & 6729 & & & & 8710 & 6.70 & 0.032 \\
\hline 4 & 760 & 31.5 & 10/14-11/14/1999 & 59 & 1153 & 1956 & 2000 & & & 2069 & 1.59 & 0.014 \\
\hline 5 & 360 & 25.7 & $11 / 12-12 / 05 / 1999$ & 71 & 14838 & 7949 & 6285 & & & 11224 & 8.63 & 0.013 \\
\hline 6 & 874 & 32.0 & $11 / 14-12 / 05 / 1999$ & 52 & & 12819 & 4216 & & & 10771 & 8.29 & 0.004 \\
\hline 7 & 1806 & 39.8 & $03 / 17-03 / 18 / 2000$ & 24 & 2372 & & & & & 3438 & 2.64 & 0.017 \\
\hline 8 & 1580 & 38.4 & $03 / 31-04 / 30 / 2000$ & 62 & 559 & 727 & 1310 & & & 1215 & 0.93 & 0.016 \\
\hline 9 & 397 & 26.0 & $12 / 02-12 / 22 / 2000$ & 120 & 949 & 710 & 1804 & 442 & 776 & 2062 & 1.59 & 0.023 \\
\hline 10 & 410 & 26.5 & $12 / 14-12 / 22 / 2000$ & 68 & 1230 & 805 & 1482 & & & 1260 & 0.97 & 0.027 \\
\hline 11 & 1858 & 40.1 & 06/04-06/19/2001 & 98 & 606 & 7476 & 238 & 6957 & & 2002 & 1.54 & 0.001 \\
\hline 12 & 364 & 25.5 & $08 / 16-09 / 01 / 2001$ & 71 & 76 & 126 & 43 & & & 73 & 0.06 & 0.017 \\
\hline
\end{tabular}


day and night (Fig. 3b). Two of the largest fish (\#7 and \#11) showed a distinct diel pattern, with most of the daytime hours spent in locations offering shade (e.g. kelp bed and pier). Like kelp bass \#7, large kelp bass were observed in the shade of the pier during the day, but left this area at night to use adjacent cobble/rocky areas along the beach and the boulder rip rap area by the pier (Fig. 3a). The human-made rip rap area consisted of large boulders with holes of sufficient size to provide shelter for fish. Visual SCUBA/snorkel-based fish counts $(30 \times 4 \mathrm{~m}$ band transects $)$ of kelp bass dur- ing the day indicated a higher density $(5.3 \pm 2.2$ fish $100 \mathrm{~m}^{-3}$ ) of adult kelp bass (>25 cm SL) under the pier and in the kelp bed canopy along the east wall of the cove than nearby sand/rocky rubble areas without shade $\left(0.7 \pm 0.6\right.$ fish $\left.100 \mathrm{~m}^{-3}\right)$.

\section{Site fidelity}

None of the 12 kelp bass tracked ever left the reserve to establish a home range in another area during the

\section{a}
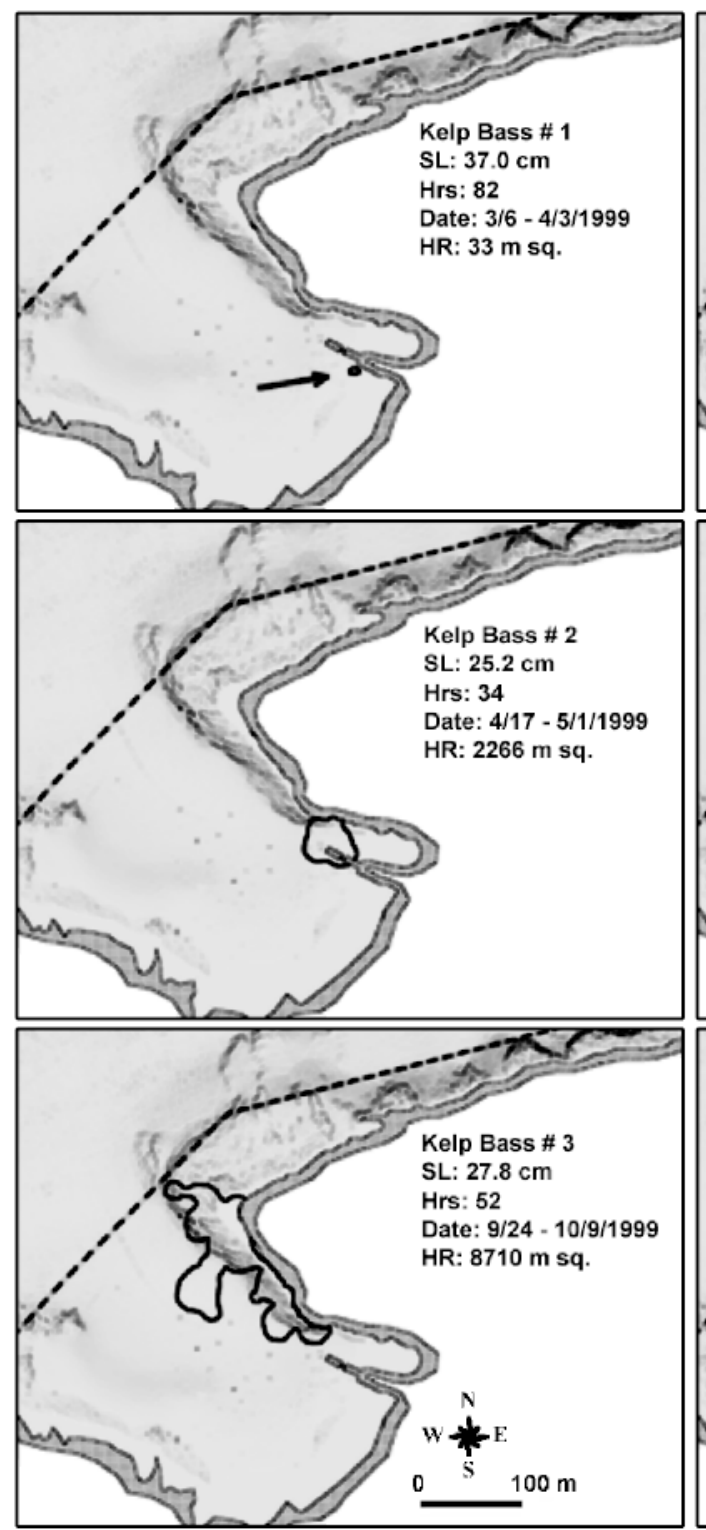
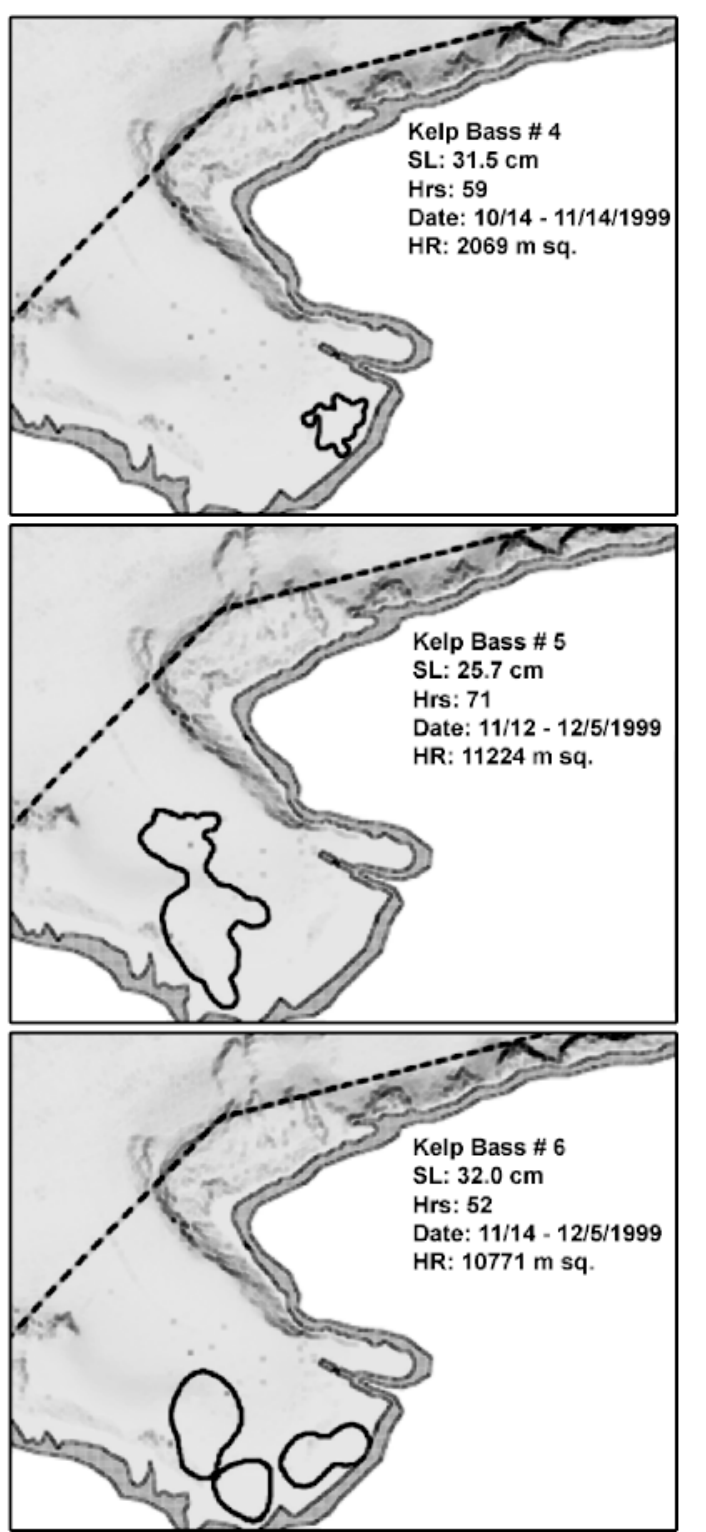

(Fig. 2 continued on next page)

Fig. 2. Paralabrax clathratus. The $95 \%$ kernel utilization distribution (KUD) home range estimates for the 12 kelp bass. (a) Kelp bass \#1 to 6 and (b) \#7 to 12. Standard length ( $\mathrm{SL}=\mathrm{cm})$, dates tracked, and home range size $\left(\mathrm{HR}=\mathrm{m}^{2}\right)$ is given for each fish. Some home ranges are represented by several polygons, representing areas of highest use 

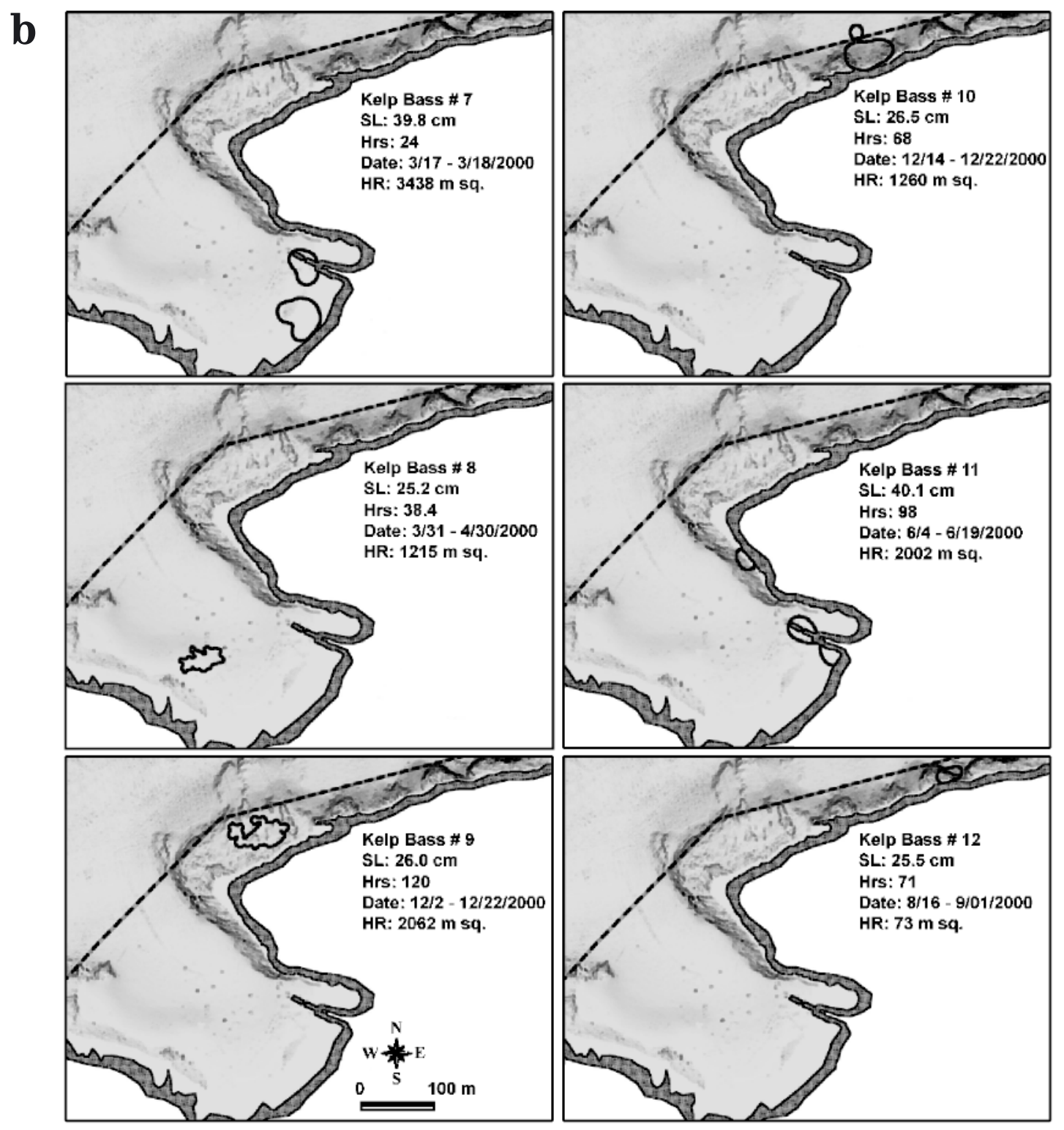

Fig. 2 (continued)

duration of the study. All fish consistently revisited the same locations during each successive $24 \mathrm{~h}$ track. The mean activity space overlap of successive tracks was $49 \pm 30 \%$, and the mean distance from the center of each daily activity space to the center (harmonic mean) of the home range was $13 \pm 16 \mathrm{~m}$. Linearity values (index 0 to 1 , with a value of 1 representing linear movement) ranged from 0.001 to 0.03 , with a mean of $0.015 \pm 0.009$. The low linearity values calculated for each fish further indicate repeated use of the same area. In addition, several tagged kelp bass were visually resighted at the same locations where they were tagged several years prior. Kelp bass \#1, initially tagged and tracked on March 6, 1999, was repeatedly resighted within $10 \mathrm{~m}$ of the core of its home range over the last 3 yr.

Acoustic monitoring of an additional 4 kelp bass (kelp bass A to D) over 4 mo indicated a daily presence within the reserve, although there was some detected movement from one area of the reserve to another (Table 2). One kelp bass (B) was observed to move from a core area within Big Fisherman's Cove to a location $\sim 1 \mathrm{~km}$ away, near the outer edge of the reserve (Pumpernickel), during several evenings in the spring, and returned back to its core area in the reserve soon after dark (Fig. 4). 
Table 2. Paralabrax clathratus. Number of days acoustically monitored kelp bass were detected at various locations throughout Catalina Marine Science Center Marine Life Refuge (CMLR). SL = standard length $(\mathrm{cm})$. Time at liberty is the number of days between the date of release and the last detection of that fish by any monitor. Pier monitor was non-functional after 05/25/2002.

NA: no monitor coverage at those locations during this portion of the study

\begin{tabular}{|lcccccccccc|}
\hline $\begin{array}{l}\text { Kelp } \\
\text { bass }\end{array}$ & $\begin{array}{c}\text { Date released } \\
(\mathrm{mm} / \mathrm{dd} / \text { Yyyy) }\end{array}$ & $\begin{array}{c}\text { SL } \\
(\mathrm{cm})\end{array}$ & $\begin{array}{c}\text { Pier } \\
(\mathrm{d})\end{array}$ & $\begin{array}{c}\text { East Wall } \\
(\mathrm{d})\end{array}$ & $\begin{array}{c}\text { Chaulk } \\
\text { Cliff }(\mathrm{d})\end{array}$ & $\begin{array}{c}\text { Intake } \\
\text { Pipes (d) }\end{array}$ & $\begin{array}{c}\text { 3 Caves } \\
(\mathrm{d})\end{array}$ & $\begin{array}{c}\text { Pumpernickel } \\
(\mathrm{d})\end{array}$ & $\begin{array}{c}\text { Time at } \\
\text { liberty (d) }\end{array}$ & $\begin{array}{c}\text { Location } \\
\text { released }\end{array}$ \\
\hline $\mathrm{A}$ & $06 / 06 / 2000$ & 25.1 & 147 & 147 & 147 & NA & NA & NA & 147 & Chaulk Cliffs \\
B & $03 / 23 / 2002$ & 47 & 62 & 76 & 76 & 14 & 6 & 5 & 76 & Pier \\
C & $04 / 12 / 2002$ & 42 & 0 & 0 & 0 & 45 & 156 & 10 & 156 & 3 Caves \\
D & $04 / 12 / 2002$ & 27.5 & 2 & 2 & 1 & 47 & 50 & 15 & 50 \\
\hline
\end{tabular}

\section{Habitat utilization and preference}

The categories of geological habitat type as determined by multibeam side-scan sonar were generally described as rock wall ( $\mathrm{RW}_{;}>15^{\circ}$ slope, solid bedrock), steep rock rubble $\left(\mathrm{SRR}_{;}>12^{\circ}\right.$ slope, loose rocks over bedrock), rock boulders ( $\mathrm{RB}$; rocks $>1 \mathrm{~m}$ diam.), rock rubble $\left(\mathrm{RR}_{i}<12^{\circ}\right.$ slope), and $\mathrm{mud} /$ sand $\left(\mathrm{M} / \mathrm{S}_{i} \mathrm{H} . \mathrm{G}\right.$. Greene \& R. Kvitek unpubl. data) (Fig. 5). Kelp bass showed the highest average percent utilization for M/S $(41 \pm 39 \%)$ followed by SRR $(23 \pm 40 \%)$, RR $(19 \pm 28 \%)$, RB (12 $\pm 24 \%)$ and RW (5 $\pm 10 \%)$ (Fig. 6). Average percent utilization of areas with kelp Macrocystis pyrifera (biological habitat) was $55.5 \pm 37.8 \%$ (Fig. 6). Among all the fish that spent time over $\mathrm{M} / \mathrm{S}, 47 \%$ of that time was spent associated with kelp or artificial vertical structure in that habitat (i.e. mooring lines, floating pier), whereas $91 \%$ of the time that all fish spent over rock substrate they were also associated with kelp. Kelp bass showed the greatest habitat selection preference for RB (4.62 \pm 11.57$)$ followed by RR (1.62 \pm 0.37$)$, RW (0.68 \pm 0.53$), \operatorname{SRR}(0.67 \pm 0.69)$, and M/S (0.63 \pm 1.85). Kelp bass also exhibited a preference for giant kelp $(1.72 \pm 1.22)$ (Fig. 6). There was no relationship between home range size (KUD) and the percentage of any habitat utilized within each fish's home range (multiple regression: $\mathrm{r}^{2}=0.23, \mathrm{p}=0.86$ ).

\section{DISCUSSION}

\section{Home range}

The home range sizes of adult kelp bass tracked in our study varied considerably among individuals (33 to $11224 \mathrm{~m}^{2}$ ), and in some cases activity-space sizes varied from day to day within individuals (Table 1). While variability in home range size and shape is common among fishes, there are numerous factors that can influence it (Kramer \& Chapman 1999). Although home range size has been correlated with body size in some fish (e.g. Morrissey \& Gruber 1993, Kramer \&
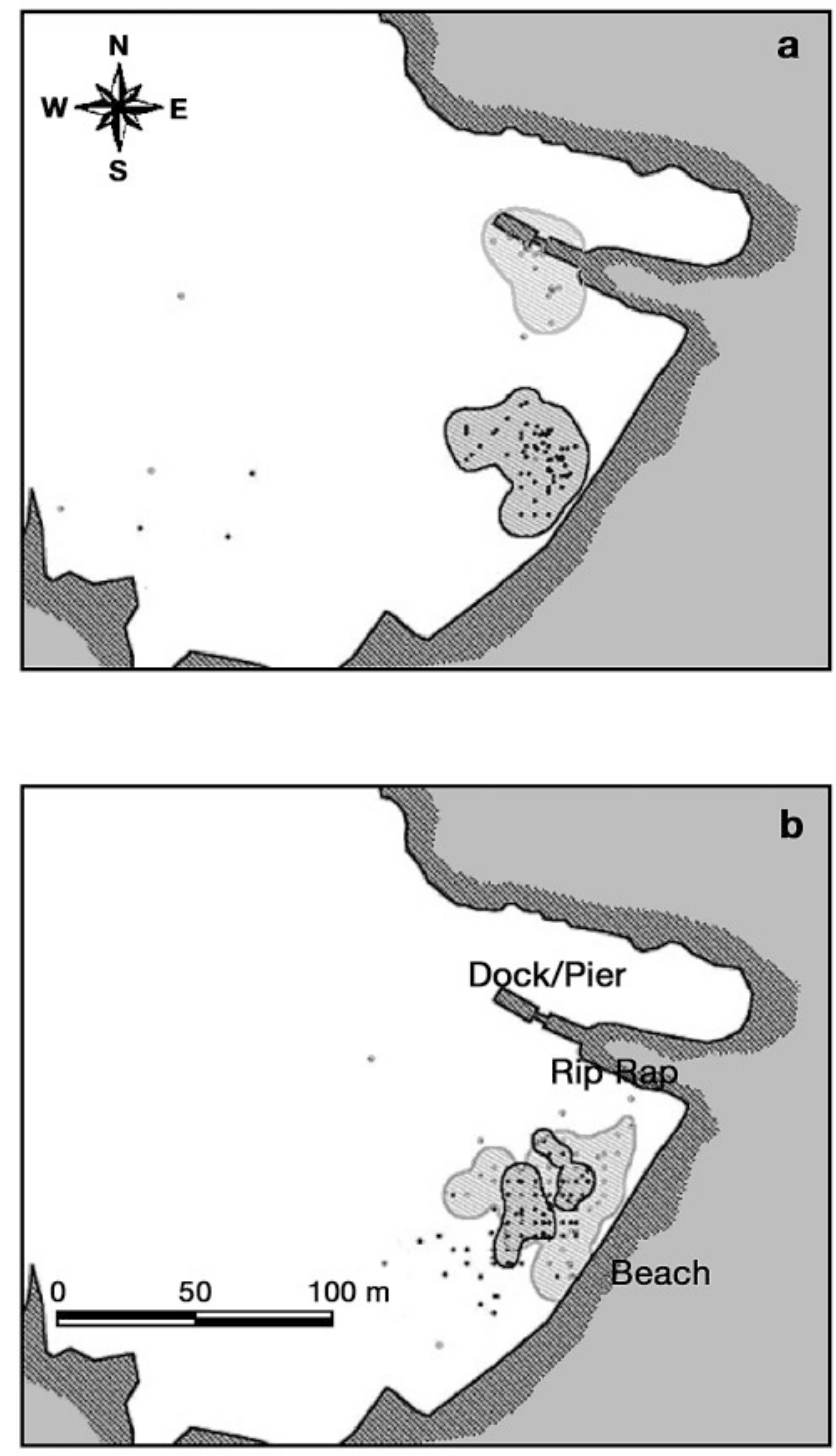

Fig. 3. Paralabrax clathratus. Day/night activity space locations (KUDs) for (a) kelp bass \#7 and (b) \#4. Gray dots represent daytime position fixes and black dots represent nighttime position fixes 

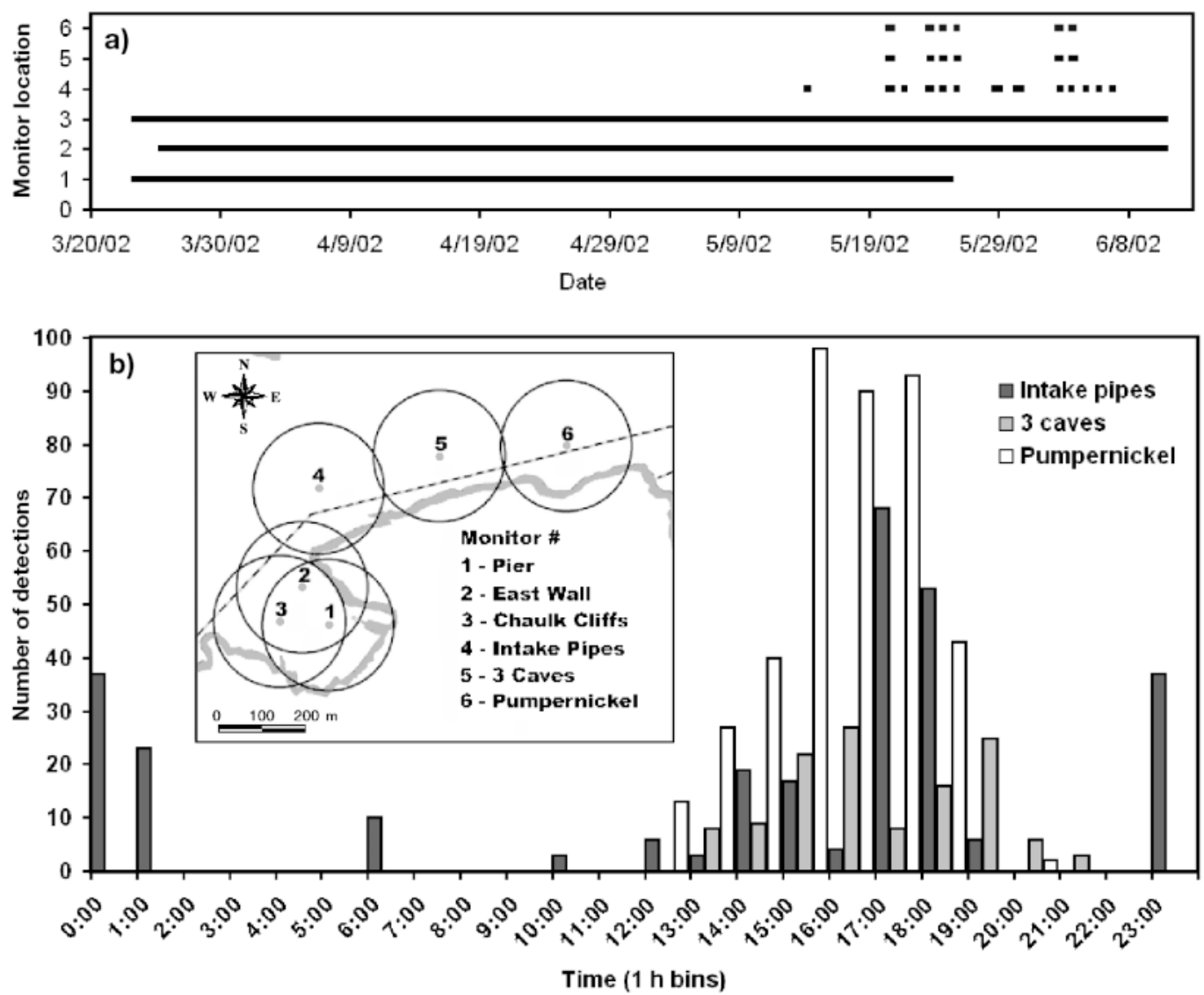

Fig. 4. Paralabrax clathratus. (a) Time series of acoustic detections (represented by dots or lines) for kelp bass B by acoustic monitors in the reserve from March to June 2002. Monitor locations and numbers are illustrated on inset map and correspond to monitor locations on the graph. Black rings surrounding monitor locations (gray circles) represent a $150 \mathrm{~m}$ detection radius.

(b) Frequency of detections by time of day for kelp bass B at the Intake Pipes, 3 Caves, and Pumpernickel monitors

Chapman 1999), we found no relationship between fish size and home range size for kelp bass tracked in our study. It is possible that much of the variability observed in home range size among individuals is attributed to other factors such as season, sex of fish, and/or habitat availability and composition.

We were unable to determine the sex of any of the kelp bass tracked in this study, but it is possible that some of the variability in home range sizes among individual fish was attributed to differences in space use by males and females. Other studies on the movement patterns of tropical serranids have found similar differences in home range size among individuals regardless of body size. Shpigel \& Fishelson (1991) found that territorial males of the tropical serranid Cephalopholis miniata had larger home ranges than the females, which was attributed to the males' need to patrol their territories and protect their harems. However, we saw no evidence of territorial behavior or harem utilization in kelp bass in our study area, so it is unlikely that the high variability in home range size is solely attributable to differences in sex.
It is also possible that some of the variability in daily space use during spring and summer months was attributable to spawning behavior. There have been indications that some kelp bass exhibit summer spawning migrations and may move to offshore reefs to group spawn (Love 1996). Two fish were tracked during summer months (kelp bass \#11 and \#12, Table 1, Fig. 2b) and neither fish moved offshore or exhibited migratory offshore movements. Although kelp bass \#11 did show the greatest individual variability in daily space use, there was no direct evidence that these movements were attributable to spawning behavior. However, 1 of the kelp bass tagged with a coded transmitter (B) exhibited movements up to $1 \mathrm{~km}$ out of the cove and along the boundary of the reserve during several evenings in the spring. Kelp bass are reported to spawn from late spring through summer months and are found to occur around nautical twilight (B. Erisman pers. comm.), so considering the seasonal and daily timing of movements of kelp bass $B$, it is possible that this movement was associated with spawning behavior (Fig. 4). 


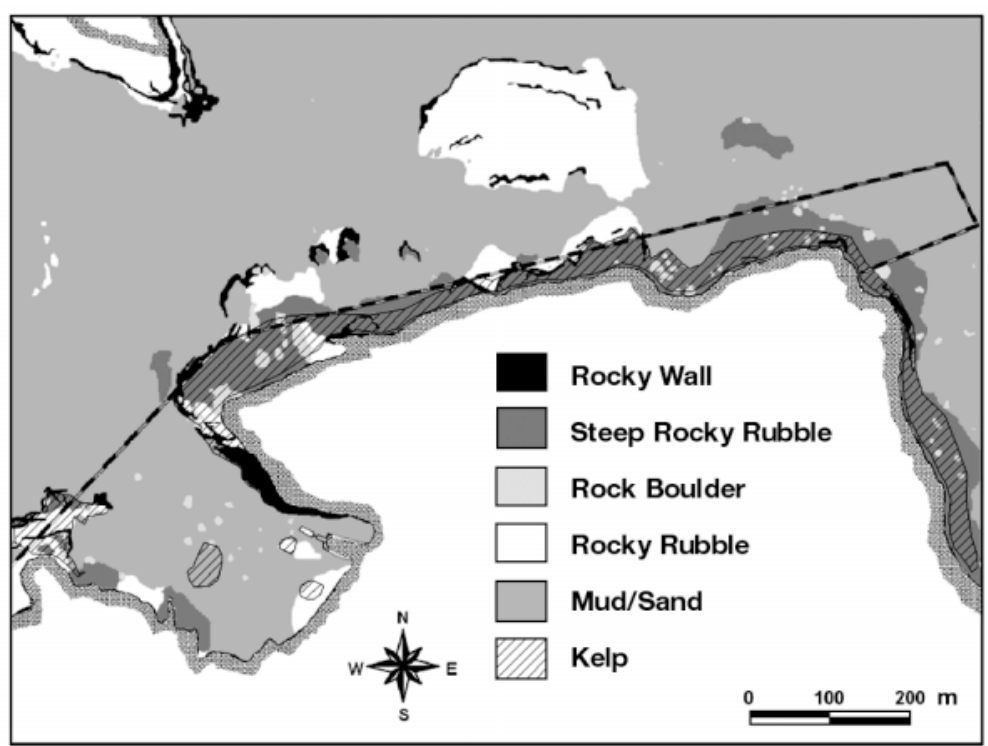

Fig. 5. Habitat map showing areas of rock wall ( $>15^{\circ}$ slope solid bedrock), steep rock rubble $\left(>12^{\circ}\right.$ slope, loose rocks over bedrock), rock boulders (rocks $>1 \mathrm{~m}$ diam.), rock rubble $\left(<12^{\circ}\right.$ slope), mud/sand, and kelp in Catalina Marine Science Center Marine Life Reserve (CMLR) and surrounding areas

around artificial habitats (pier and rip rap) generally exhibited small home ranges compared to those tracked in the middle portion of Big Fisherman's Cove (\#5, 6, 8; Fig. 2a,b). The pier and rip rap habitat consists of high vertical relief, large holes, shade and lights on the pier that tend to attract bait fish, therefore kelp bass may not have to venture far to find prey. This is further supported by the higher densities of large kelp bass found around these artificial habitats than adjacent natural habitats. The middle of the cove, however, consists of sand substratum with large mooring blocks (ca. $30 \mathrm{~m}$ apart) that provide interspersed substrate for giant kelp Macrocystis pyrifera, which offers high vertical relief in a relatively barren habitat. Due to the small area these interspersed habitats provide, kelp bass residing in these areas may have to visit several kelp patches in order to access sufficient forage base, thereby increasing their daily activity space sizes. Similar observations have been made for

Although there was no statistical relationship between the home range size and the percentage of various habitat used within the home range, qualitative observations of habitat utilization may explain some of the variability in home range size among kelp bass in this study. Kelp bass (\#1, 2, 7, 11; Fig. 2a,b) tracked

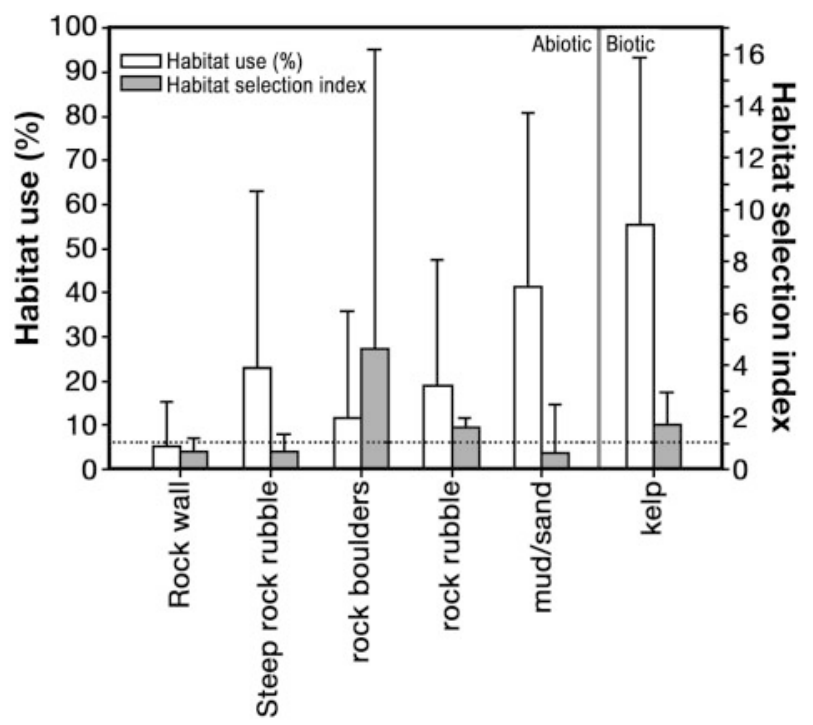

Fig. 6. Paralabrax clathratus. Mean percent habitat use and preference (habitat selection index; HSI) of rock wall, steep rock rubble, rock boulders, rock rubble, mud/sand, and giant kelp by 12 kelp bass tracked in Catalina Marine Science Center Marine Life Reserve (CMLR). Horizontal dotted line indicates an HSI value of 1 several species of rockfishes. Matthews (1990a,b) found that copper Sebastes caurinus and quillback rockfish $S$. maliger had smaller home ranges on rocky reefs with higher vertical relief than on more low-lying reefs. They also had smaller home ranges on artificial reefs than natural reefs; however, this trend varied with seasonal kelp loss. Rockfish on high-relief reefs maintained small home ranges throughout the season. It was assumed that the higher relief habitats supported higher densities of prey and shelters than the low relief habitats, therefore allowing rockfish to have smaller home ranges. This is very similar to observations made for many kelp bass in CMLR.

\section{Activity patterns}

Kelp bass were active and used similar amounts of space during both day- and nighttime periods. Hobson et al. (1981) hypothesized that kelp bass may undergo an ontogenetic shift in activity pattern associated with a change in diet. Juveniles are active throughout the day, foraging on zooplankton, and then shelter in vegetation at night, whereas subadults may feed at night, particularly if they move out over sand (Hobson \& Chess 1986). Adults are thought to be more piscivorous and feed more during crepuscular periods. Although we were not able to quantify rates of movements due to the small areas that most fish used, there were instances when some kelp bass made directed movements during dusk periods. While some of the kelp bass exhibited a high degree 
of overlap in day- and nighttime area use (\#4; Fig. 3b), several kelp bass tagged under the pier used different habitat during nighttime periods. Kelp bass \#7 moved from the shaded area under the pier during the day to an adjacent cobble beach area at night (Fig. 3a). This shift in habitat may facilitate feeding at different times of day. During the day adult kelp bass are frequently found in areas offering shade (e.g. kelp, under pier, or in large holes), which may increase their ability to see and surprise prey swimming in sunlit areas (Helfman 1981); however, this advantage is lessened at night. Bait fish were often observed forming shoals along the cobble beach where several kelp bass spent their night, so it is possible that they moved to this area to take advantage of the consolidation of prey.

\section{Site fidelity}

All of the adult kelp bass tracked over repeated diel cycles showed a high degree of site fidelity. Even kelp bass that exhibited large variability in daily activity spaces showed a large degree of overlap in area use. This observation is further supported by the low linearity index calculated for each fish, indicating little directed movement. Nonetheless, the degree of site fidelity in kelp bass may vary with age. In a tag and recapture study on kelp bass at Santa Catalina Island, Young (1963) found that smaller fish were more likely to be caught farther from their initial capture site than larger fish. This suggests that juvenile kelp bass may be more likely to move than larger adults. Hartney (1996) found that juvenile kelp bass captured in Bird Rock and transplanted to Isthmus Reef showed minimal homing response and did not return to the site of capture. While homing behavior was not tested in our study, adult kelp bass did make occasional forays outside their typical home range area, but would return to those areas within a day. Data from acoustic monitoring at CMLR have shown that kelp bass instrumented with individually coded transmitters show a high degree of site fidelity for up to 4 mo (nominal battery life of these transmitters). However, several fish traveled over $1 \mathrm{~km}$ from their core home range and returned to their core site within 3 to 4 h. In addition, some of the fish have been resighted by divers within their home ranges up to $3 \mathrm{yr}$ after they were tagged. This evidence suggests that many of the fish tracked exhibit multiple-year site fidelity to home ranges.

\section{Habitat utilization}

By layering fine-scale kelp bass positional fixes over a high-resolution habitat map, we were able to deter- mine what types of habitats kelp bass in the CMLR prefer and in what proportions. Adult kelp bass tracked in the CMLR were found over hard substratum (rock wall, steep rock rubble, rock boulders, or rock rubble) $59 \%$ of the time and over mud/sand $41 \%$ of the time (Fig. 6). However, a majority of the time that kelp bass were found over rock substratum and mud/sand, they were also strongly associated with kelp found in both of those habitats. Macrocystis pyrifera was the only macroalgae quantified as biotic habitat due to its predominance throughout the reserve. Kelp was generally found over rock substratum, but also occurred in the middle of the cove where sand substratum was most abundant. Much of the kelp in the middle of the cove was growing off large mooring blocks or occasional rock boulders. Kelp bass were found in kelp $55.5 \%$ of the time and exhibited a strong habitat selection preference for this type of habitat (HSI $=1.72$ ) relative to its availability. Previous studies have found that giant kelp is of great importance to recruiting and juvenile kelp bass (Holbrook et al. 1990, Carr 1996), but less important for adults. Although kelp bass are considered a rocky reef- and kelp-bed-associated species, they are also known to use mud/sand habitats bordering rock reefs (Hobson \& Chess 1986, Johnson et al. 1994). Kelp bass in our study observed over mud/sand habitat were frequently within $10 \mathrm{~m}$ of rock substratum or kelp. Adult kelp bass are less susceptible to predation than recruits and juveniles; therefore, they may be able to move further away from kelp.

Of the rock substratum, fish were most often found over steep rock rubble $(23 \%)$ and rock rubble $(19 \%)$. While it may appear, based on percent utilization, that adult kelp bass also show a strong preference for mud/sand (flat habitat) relative to the total available habitat, they show a much lower habitat selection preference for $\mathrm{mud} /$ sand $(\mathrm{HSI}=0.63$ ) than rock boulder substratum (HSI = 4.6) (high relief habitat). Therefore, kelp bass may be moving to mud/sand substratum for additional feeding opportunities not afforded along the rocky reefs or kelp beds. Adult kelp bass in CMLR likely prefer rock-boulder habitat for the same reasons they prefer the artificial habitats (e.g. pier and rip rap), because they offer high vertical relief, shade and large holes.

\section{Reserve effectiveness}

An effective marine reserve should be large enough to encompass the daily movement patterns of adult fish, which may vary depending on habitat composition and availability, season, and conspecific density. Barrett (1995) suggested that a marine reserve diameter should be, at minimum, an order of magnitude 
larger than the daily movements of the most wideranging residents in order to effectively protect target species. Home ranges of kelp bass were small (average $3 \%$ ) in relation to the size of the CMLR. In addition, only 1 of the 12 kelp bass tracked in our study moved beyond the boundary of the reserve, and none permanently left the reserve. If the fish tracked in this study are representative of other adults within the CMLR population, then these data indicate that this size of reserve is effective in protecting kelp bass reproductive stock.

So, what makes this reserve size adequate for adult kelp bass? Although no correlations were found between use of various habitat types and home range size, habitat clearly has a strong influence on kelp bass movement patterns. As one might expect, fish with home ranges centered closer to the boundary of the reserve may be more likely to cross the boundary than those using habitat farther within the reserve (Kramer \& Chapman 1999); however, 2 of the 3 kelp bass tracked along the narrow northern edge of the reserve did not cross the reserve boundary (\#9 and 12; Fig. 2b). This is most likely attributed to the natural habitat break that occurs close to the reserve boundary. Bird Rock and Isthmus Reef offer comparable rock and kelp habitat but are separated from the reserve boundary by $\sim 200 \mathrm{~m}$ of sand substratum (depth $\sim 30$ to $40 \mathrm{~m}$ ) (Figs. 1 \& 5). Several of the kelp bass tracked within the reserve were observed moving distances greater than $200 \mathrm{~m}$ over shallow sand areas traveling between small patches of interspersed kelp in the cove; however, none of the kelp bass tracked were observed moving to Bird Rock or Isthmus Reef. This suggests that the deeper habitat break bordering CMLR may serve as a natural boundary for kelp bass, thereby restricting their home ranges. Barrett (1995) also found that natural habitat boundaries were effective in minimizing emigration and shortand long-term movements of labrid fishes in Tasmania.

Although it was not our goal to measure the spillover potential of CMLR, it is important to note that there have been higher densities of larger kelp bass observed inside CMLR than outside (J. Caselle unpubl. data), yet none of the fish we tracked left the reserve to establish home ranges outside the boundaries. It is possible that we did not observe spillover of adult kelp bass because there is not a significant density gradient across the reserve boundary. It is also possible that if any spillover exists, it may be dominated by juveniles, which are displaced due to density-dependent competition with adults or other species. Future studies should focus on quantifying the movements of juvenile kelp bass as well as the effects of density-dependent spillover.
Acknowledgements. Thanks go to Wrigley Marine Science Center and the Ocean Studies Institute for facilities support and to B. Mercier and J. McKibben for their assistance with boats and equipment. Special thanks go to C. Snellen, C. Carr, G. Moss, M. Marcotte, J. Vaudo, K. Johnson, S. Snider, M. Galima, C. Cain, C. Peckham, and the countless others who helped with the long tedious hours of tracking. Thanks also go to H. G. Greene and R. Kvitek for the bathymetry and habitat maps of CMLR and to J. Caselle, K. Goldman, and G. Goodmanlowe for their thoughtful reviews of this manuscript. Funding and resources for this study were provided by USC Sea Grant and NOAA (grant no. NA86RG0054), California State University Long Beach Scholarly and Creative Activities grant, and Performance Diver. This project was approved by the California State University Long Beach Animal Care and Welfare Committee (\#186). Contribution \#226 from the Wrigley Marine Science Center on Santa Catalina Island.

\section{LITERATURE CITED}

Allen LG, Hovey TE (2001) Kelp bass. In: Larson EJ (ed) California's living marine resources: a status report. University of California Press, Davis, CA, p 222-223

Barrett NS (1995) Short- and long-term movement patterns of six temperate reef fishes (Families Labridae and Monacanthidae). Mar Freshw Res 46:853-860

Carr MH (1996) Effects of macroalgal dynamics on recruitment of a temperate reef fish. Ecology 75:1320-1333

Dahlgren C, Sobel J (2000) Designing a Dry Tortugas ecological reserve: how big is big enough? Bull Mar Sci 66: $707-719$

Hartney KB (1996) Site fidelity and homing behaviour of some kelp-bed fishes. J Fish Biol 49:1062-1069

Helfman GS (1981) The advantages to fishes of hovering in shade. Copeia 1981:392-400

Hobson ES, Chess JR (1986) Relationships among fishes and their prey in a nearshore sand community off southern California. Environ Biol Fish 17:201-226

Hobson ES, McFarland WN, Chess JR (1981) Crepuscular and nocturnal activities of California nearshore fishes, with consideration of their scotopic visual pigments and the photic environment. US Fish Bull 79:1-30

Holbrook SJ, Carr MH, Schmitt RJ, Coyer JA (1990) Effect of giant kelp on local abundance of reef fishes: the importance of ontogenetic resource requirements. Bull Mar Sci 47:104-114

Holland KN, Peterson JD, Lowe CG, Wetherbee BM (1993) Movements, distribution and growth rates of the white goatfish Mulloides flavolineatus in a fisheries conservation zone. Bull Mar Sci 52:982-992

Holland KN, Lowe CG, Wetherbee BM (1996) Movements and dispersal patterns of blue trevally (Caranx melampygus) in a fisheries conservation zone. Fish Res 25:279-292

Hooge PN, Eichenlaub WM (2000) Animal movements extension to ArcView. Alaska Biological Center, US Geological Survey, Anchorage

Johnson TD, Barnett AM, DeMartini EE, Craft LL, Ambrose RF, Purcell LJ (1994) Fish production and habitat utilization on a southern California artificial reef. Bull Mar Sci 55:709-723

Kramer D, Chapman M (1999) Implications of fish home range size and relocation for marine reserve function. Environ Biol Fish 55:65-79

Kulbicki M (1998) How the acquired behaviour of commercial reef fishes may influence the results from visual censuses. J Exp Mar Biol Ecol 222:11-30 
Limbaugh C (1955) Fish life in the kelp beds and the effects of kelp harvesting. Report No. IMR Ref 55-9, University of California Institute of Marine Research, San Diego

Love MS (1996) Probably more than you wanted to know about the fishes of the Pacific coast. Really Big Press, Santa Barbara

Lowry MB, Suthers IM (1998) Home range, activity and distribution patterns of a temperate rocky-reef fish, Cheilodactylus fuscus. Mar Biol 132:569-578

Matthews KR (1990a) An experimental study of the habitat preferences and movement patterns of copper, quillback, and brown rockfishes (Sebastes spp.). Environ Biol Fish 29:161-178

Matthews KR (1990b) A telemetric study of the home ranges and homing routes of copper and quillback rockfishes on shallow rocky reefs. Can J Zool 68:2243-2250

Meyer CG, Holland KN, Wetherbee BM, Lowe CG (2000) Movement patterns, habitat utilization, home range size and site fidelity of whitesaddle goatfish, Parupeneus porphyreus, in a marine reserve. Environ Biol Fish 59:235-242

Miller DJ, Lea RN (1972) Guide to the coastal marine fishes of California. Calif Fish Game Bull 157:1-249

Mitamura H, Arai N, Sakamoto W, Mitsunaga Y and 5 others (2002) Evidence of homing of black rockfish Sebastes inermis using biotelemetry. Fish Sci 68:1182-1188

Morrissey JF, Gruber SH (1993) Home range of juvenile lemon sharks Negaprion brevirostis. Copeia 1993: $425-434$

Quast J (1968) Observations on the food and biology of the kelp bass, Paralabrax clathratus with notes on its sport fishery at San Diego, California. US Fish Bull 139:81-108

Roberts CM (2000) Selecting marine reserve locations: optimality versus opportunism. Bull Mar Sci 66:581-592

Roberts CM, Bohnsack JA, Gell F, Hawkins JP, Goodridge R (2001) Effects of marine reserves on adjacent fisheries. Science 294:1920-1923

Editorial responsibility: Otto Kinne (Editor), Oldendorf/Luhe, Germany
Rodgers-Bennett L (1991) Fisheries review. Report No. 42. California Cooperative Oceanic Fisheries Investigations, San Diego

Seaman DE, Millspaugh JJ, Kernohan BJ, Brundige GC, Raedeke KJ, Gitzen RA (1999) Effects of sample size on kernel home range estimates. J Wildl Man 63:739-747

Shpigel M, Fishelson L (1991) Territoriality and associated behaviour in three species of the genus Cephalopholis (Pisces: Serranidae) in the Gulf of Aqaba (Red Sea). J Fish Biol 38:887-896

Starr RM, Heine JN, Felton JM, Cailliet GM (2002) Movements of bocaccio (Sebastes paucispinis) and greenspotted (Sebastes chlorostictus) rockfishes in a Monterey submarine canyon: implications for the design of marine reserves. US Fish Bull 100:324-337

Walters C (2000) Impacts of dispersal, ecological interactions, and fishing effort on efficacy of marine protected areas: how large should protected areas be? Bull Mar Sci 66: $745-757$

Winter JD, Ross MJ (1982) Methods in analyzing fish habitat utilization from telemetry data. In: Armantrout N (ed) Proc Symp Acquisition and Utilization of Aquatic Habitat Inventory Information. American Fisheries Society Western Division, p 273-279

Worton BJ (1987) A review of models of home range for animal movements. Ecol Model 38:277-298

Young PH (1963) The kelp bass (Paralabrax clathratus) and its fishery, 1947-1958. Calif Fish Game Fish Bull 122:1-67

Zeller DC (1997) Home range and activity patterns of the coral trout Plectropomus leopardus (Serranidae). Mar Ecol Prog Ser 154:65-77

Zeller D (1999) Ultrasonic telemetry: its application to coral reef fisheries research. US Fish Bull 97:1058-1065

Zeller DC, Russ GR (1998) Marine reserves: patterns of adult movement of the coral trout (Plectropomus leopardus [Serranidae]). Can J Fish Aquat Sci 55:917-924

Submitted: November 28, 2002; Accepted: April 3, 2003

Proofs received from author(s): June 23, 2003 